\title{
Analysis of the Possibility of Used of the Quality Management Techniques with Non- Destructive Testing
}

\author{
Andrzej PACANA*, Dominika SIWIEC
}

\begin{abstract}
The quality of products is, in particular, analyzed in product case from the aerospace industry in order to achieve the desired quality and safety levels. The aim of the study is to propose the use of selected quality management techniques in the quality control process made by non-destructive testing. The subject of the research were two products made of steel 410 , in which incompatibilities were detected relatively frequently. It was a four-hole flange bearing housing and a gasodynamic sealant. The products mentioned were subjected (according to the quality procedure) to non-destructive testing with two methods: a fluorescent and a magnetic-powder. In order to identify the source cause of incompatibilities the implementation of selected quality management techniques was proposed. These techniques were: $5 \mathrm{~W} 2 \mathrm{H}$ method, Ishikawa method and 5 Why method. Although these methods are simple, they were not used in the enterprise so far. So it was an order to use them, to check their adequacy. By supplementing the non-destructive research with the proposed sequence of selected quality management techniques, it was shown that it is possible to identify the source cause. In addition, by indicating the source cause it is possible to propose improvement actions adequate to the problem. So it will improve the quality of the next products. The proposed solution using the $5 \mathrm{~W} 2 \mathrm{H}$ method, Ishikawa diagram and 5 Why method is complete and easy in practice technique for qualitative analysis to identify the root cause of incompatibility. After using these not complicated methods, it will be effective to use in the appropriate sequence more advanced methods, such as 8D, Six Sigma and DMAIC.
\end{abstract}

Keywords: non-destructive testing; root cause analysis; quality control; quality management; quality management techniques

\section{INTRODUCTION}

In aviation industry the products are subjected to specific quality controls in order to achieve the desired level of quality and safety. The types of researches to which the metal products are subjected are destructive and non-destructive testing $[1,2]$. In destructive testing (DT) in order to make an assessment of the mechanical properties, the sample collected for testing is destroyed. Thus, the destructive tests are mainly used for complex objects, for which it is not possible to make research with other methods. To diagnose the product the non-destructive tests are more often used (NDT), which allow making a quality analysis of the product without destroying it [3]. In comparison to destructive tests, the non-destructive tests are less expensive. The literature of the subject gives many examples of non-destructive testing and their use. With using the ultrasonic method, the quality research of single adhesive joints in plate constructions was carried out, for example: alloys after the technological process [4], PCB plates with metal core [5], steel bridges [6], the inside of metallic sample, gas turbines, quality of pipes from plastic reinforced with carbon fibre (CFRP) of different geometries. This method was improved in order to increase the signal-to-noise ratio of defect (SNR) [7] and distinguish transitional signals and noises, or monitor the corrosion of steel. The research of the dependence of parameters was made, e.g., temperature and velocity of ultrasound propagated, propagation of ultrasound waves, creep degradation in welded steel joint [8]. By means of eddy currents, the depth of incompatibilities and quality of metal products or coating were measured $[9,10]$, mechanical properties [11], the parameters used in research were analyzed e.g. signal [12], speed, sensitivity [13, 14], step frequency. The quality analysis of products was made by using the methods like penetration and magnetic-powder, where the penetration method was used to identify the incompatibilities on the surface, and the magnetic-powder method was used to identify the incompatibilities on the surface and under the surface. Improvements were made to increase the effectiveness of these methods, and, among others the effect of fluorescent dye sensitivity on effectiveness of the research was examined, as well as the influence of the temperature and external magnetic field on the magnetic field sensor, the influence of initial magnetization on the magnetic memory signal, also the multi-layered structure of a magnetic focusing sensor was made, which allows detection of a greater non-compliance. Other applications of non-destructive testing, as well as literature review of the subject are discussed in the paper by Hristoforou E. [15]. The analysis of literature of the subject shows numerous items devoted to the issue of nondestructive testing. It was noted that non-destructive testing found the applications in case of complex problems about mechanical products [16], and also that nondestructive testing was used e.g.: to analyse the quality of products to identify the incompatibilities, to analyse dependencies between material and parameters, to analyse the change of product shape; and some research was done to improve the way of non-destructive testing. In the subject literature, no activities were undertaken to extend the research to additional qualitative analyses. It was concluded that after identifying the incompatibilities with the use of the non-destructive testing no actions were taken thanks to which it would be possible to identify the cause of incompatibilities.

In order to perform effective qualitative analyses, only non-destructive testing is insufficient. By using the commonly used tools considered as useful for nondestructive testing, it is only possible to detect incompatibilities of products, because they only provide preliminary information on incompatibilities [17], and for the enterprises, whose priority is to achieve the highest quality of products, only the identification of the incompatibilities is insufficient. Thus, after performing the non-destructive testing after which incompatibilities were identified, it is necessary to conduct further analyses in order to identify the source of these incompatibilities, which is an effective way to completely eliminate them or 
significantly minimize their creation. The presented research and the comparison research focus on results and conclusions and do not focus on finding the source of the identified incompatibilities. This issue is left open. Therefore, it seems useful to use non-destructive testing with selected techniques of quality management. The aim of this integration of non-destructive testing and techniques of quality management would be achieved as a part of the continuous improvement of increasingly higher quality products. Due to the variety of quality management techniques, it seems correct because of the character of the problem to use only the selected techniques and to use them in the right order, e.g. the $5 \mathrm{~W} 2 \mathrm{H}$ method, Ishikawa diagram and 5 Why method. In the paper, the integration of the listed techniques with the process of non-destructive testing was proposed. Although these methods are simple they were not used in the enterprise so far. So it was an order to use them to check their adequacy. The proposed solution with the used $5 \mathrm{~W} 2 \mathrm{H}$ method, Ishikawa diagram and 5Why method is complete and easy to practice technique to make quality analyses to identify the source cause of incompatibilities. The used technique in the process of non-destructive testing is the way for effective quality management. It can be used to solve other quality problems, and also in other enterprises as a part of improving the production processes. After using these not complicated methods, it will be effective to use more advanced methods such as 8D, Six Sigma and DMAIC in the appropriate sequence.

\section{THE SELECTION OF NON-DESTRUCTIVE TESTING METHOD}

The use of non-destructive testing sometimes does not bring the expected results, and it could be a result of inadequate selection of the method to analyze the problem or material $[2,17]$. One of the basic non-destructive tests includes visual, ultrasound, magnetic-powder, radiographic, eddy current and penetration tests [18]. The characteristics of basic non-destructive tests are presented in Tab. 1.

In the enterprise in which the analysis was made, the non-destructive tests were conducted using the fluorescent and magnetic-powder method, due to the possibility of making effective, uncomplicated quality analyses of products at relatively low costs of services (compared to other non-destructive testing methods). It was concluded that it will be effective for the enterprise to demonstrate that it is possible to implement the sequence of technique in these two methods, so in tests by the fluorescent and magnetic - powder methods. The choice of the method for the analysis of the product was conditioned: type of material from which the products were made, as well as the order from external customers. Because the magneticpowder method is applicable only to the ferromagnetic material, the gasodynamic sealant, which was ferromagnetic, was analyzed. In turn, the fluorescent flange method was used to analyze the four-hole bearing housing.

\begin{tabular}{|c|c|c|}
\hline Method & Surface & $\begin{array}{l}\text { Main advantages and } \\
\text { disadvantages }\end{array}$ \\
\hline 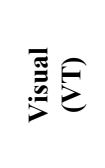 & $\begin{array}{l}\text { analysis from the inside of } \\
\text { the complex products; one } \\
\text { access place could be } \\
\text { enough; } \\
\text { clean surface; }\end{array}$ & $\begin{array}{l}\text { comprehensive; theuse the } \\
\text { optical tools } \\
\text { is necessary; uncertainty; }\end{array}$ \\
\hline 氖 & $\begin{array}{l}\text { open discontinuity on the } \\
\text { surface and free from } \\
\text { impurities; difficult research } \\
\text { of porous surfaces; }\end{array}$ & $\begin{array}{l}\text { only discontinuity on the } \\
\text { surface; not for porous } \\
\text { surfaces;simple; dirty; } \\
\text { all discontinuities on } \\
\text { the surface are detected } \\
\text { in one operation; }\end{array}$ \\
\hline 包 & $\begin{array}{l}\text { smooth and clean surface; } \\
\text { possible application } \\
\text { to parts with thin } \\
\text { galvanic coatings; }\end{array}$ & $\begin{array}{c}\text { only to ferromagnetic } \\
\text { materials; } \\
\text { identification only of } \\
\text { surface and subsurface } \\
\text { discontinuity; } \\
\text { demagnetization } \\
\text { is necessary } \\
\text { after the test; }\end{array}$ \\
\hline 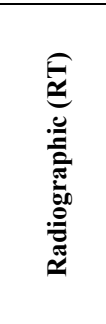 & $\begin{array}{l}\text { the access to a product from } \\
\text { external and internal side } \\
\text { is necessary; }\end{array}$ & $\begin{array}{l}\text { large surface can be tested } \\
\text { despite the high costs; the } \\
\text { depth of discontinuity is } \\
\text { not measured; } \\
\text { the direction of linear } \\
\text { discontinuity } \\
\text { is important; } \\
\text { it is considered the best } \\
\text { detection method of } \\
\text { internal incompatibilities; }\end{array}$ \\
\hline 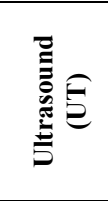 & $\begin{array}{l}\text { the access to product from } \\
\text { external or internal side is } \\
\text { necessary; } \\
\text { rough surface makes it } \\
\text { difficult or impossible to } \\
\text { study; }\end{array}$ & $\begin{array}{l}\text { high cost in the analysis of } \\
\text { a product } \\
\text { of a big construction; } \\
\text { effective to identify the } \\
\text { internal flat discontinuities; }\end{array}$ \\
\hline 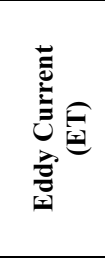 & $\begin{array}{l}\text { relatively smooth and clean } \\
\text { surface; }\end{array}$ & $\begin{array}{l}\text { For discontinuities coming } \\
\text { to or near the surface; to } \\
\text { detect thickness changes } \\
\text { of protective covers; } \\
\text { for comparing materials; } \\
\text { used for } \\
\text { magnetic and non-magnetic } \\
\text { materials; }\end{array}$ \\
\hline
\end{tabular}

\section{MATHERIALS AND METHODS}

The use of non-destructive testing has found application in the aviation industry [19], which is considered to be the leader among the sectors using the mechanical products because in the aviation industry the attention is paid to the continuous improvement of the quality of the products used. In the analyzed production and service company located in the Podkarpackie Voivodeship, the non-destructive testing was practiced to control the quality of products from the aviation industry. One of the inspected mechanical products was the fourhole flange bearing housing and the gasodynamic sealant, and these products were used in the aviation industry. It was considered important to make an analysis involving these products and propose the implementation of quality management techniques in the process of improving nondestructive testing. After detecting incompatibilities by non-destructive testing in the enterprise, the decision was made on the causes of incompatibilities without further analysis. Also, no action was taken in order to improve the quality analyses, including analyses to identify the root cause of the problems. In addition, two products were deliberately selected for analysis due to the fact that it was possible to subject them to two different non-destructive 
testing methods (fluorescent method - the four-hole flange bearing housing, magnetic-powder method, applicable only to ferromagnetic materials - a gasodynamic sealant, which was a ferromagnetic material).

The subject of the research was a four-hole flange bearing housing and a gasodynamic sealant, which were made of 410 steel, which was the nickel alloy AMS5383. Alloy AMS5383 is characterized by heat resistance and corrosion resistance. It consists of: $52,5 \mathrm{Ni}-19 \mathrm{Cr}-3,0 \mathrm{Mo}-$ $5,1 \mathrm{Cb}(\mathrm{Nb})-0,90 \mathrm{Ti}-0,60 \mathrm{Al}-18 \mathrm{Fe}$, melted in the process of homogenization and heat treatment [20].

The four-hole flange bearing housing is an easy to use and replaceable bearing assembly, thanks to which it is possible to correctly mount the bearing in the machine and ensure its correct operation. In turn, the gasodynamic sealant is a type of mechanical sealer (frontal) where a gas film is used to seal the rotating shaft, which is formed between the slip ring of the sealer. The gasodynamic sealant is used in devices with a rotating shaft, in which it is not possible to use the traditional mechanical contact sealer. This product is classified as the latest generation of mechanical sealants, and is also used in the aerospace industry. These products have influence on the work safety and effectiveness of ongoing processes.

First, the non-destructive testing by magnetic-powder method was made on the gasodynamic sealant. The research was done with the magnetic flaw detector MAG 50, which was supplied with alternating 3-phase errect current. The purity of the product after the washing operation as well as any magnetic residuals was checked. The direction of the current flow and the force lines of the magnetic field on $17 \mathrm{~kJ}$ were set on the magnetic flaw detector MAG 50. The copper pin was fixed in the product, and was then clasped in the defectoscope contacts. The surface of the product was poured with the magnetic suspension of Chemetall - MPI Diluent (HF). At 1600 A, three magnetic pulses were switched on for a minimum of $0,5 \mathrm{~s}$, where the first two were made during the pouring of the product with a slurry, and the third after finishing pouring the product with the slurry. The actions were repeated three times, every $120 \mathrm{~s}$. During the control in the magnetic time, the value of the contact field was measured, and was equal to $\geq 2,4 \mathrm{kA} / \mathrm{m}$ and was compatible with the internal instruction. The product was demagnetized after the inspection and the results were recorded.

Next, non-destructive testing with fluorescent method was subjected to a four-hole flange bearing housing. The test was started from cooling the product to a max. temperature of $40{ }^{\circ} \mathrm{C}$. Then the product was degreased (the product was immersed in the HM-406 penetrant for 30 minutes). Then the product was immersed for 10 seconds in a bath pre-rising before the process of final cleaning. The control of the product with HM-406 penetrant was made according to the instruction. The sensitivity of the penetrant was checked with the use of the master plate TAM 146040. The product was cleaned under UV lamp using a water spray with a max. temperature of $10^{\circ} \mathrm{C}-38$ ${ }^{\circ} \mathrm{C}$ (max. pressure 0,275 $\mathrm{MPa}$ ). Direct spraying on the product was made at a min. distance of $300 \mathrm{~mm}$ at lighting. The four-hole flange bearing housing was dried in a chamber dryer (max. temperature $70^{\circ} \mathrm{C}$ ). On the surface of the product a dry developer ZP-4B in the form of a powder mist was applied at the air pressure of max. $0,172 \mathrm{MPa}$ and a time of 10 minutes. After a minimum 10 minutes the excess developer was removed using the compressed air (the max. pressure $0,034 \mathrm{MPa}$ ). The control of the four- hole flange bearing housing was made in the control cabin under the UV lamp (the minimum intensity of radiation on the surface $1200 \mu \mathrm{W} / \mathrm{cm}^{2}$, the max. light intensity on the surface in cabin $20 \mathrm{~lx}$ [21]. After the inspection, the product was washed in an aqueous solution to remove the developer and residue of other materials used during the inspection.

After the non-destructive testing for the four-hole flange bearing housing and gasodynamic sealant with the use of the selected methods, the incompatibilities were identified as linear indication (Fig. 2).

In order to identify the root causes of these incompatibilities which were detected by using the nondestructive testing, it was proposed to implement quality management techniques. These techniques were: $5 \mathrm{~W} 2 \mathrm{H}$ method, Ishikawa diagram and 5Why method. Due to the fact that these techniques are complementary, in order to achieve effective results from the analysis, it was proposed to use them in a sequential manner (Fig. 1).

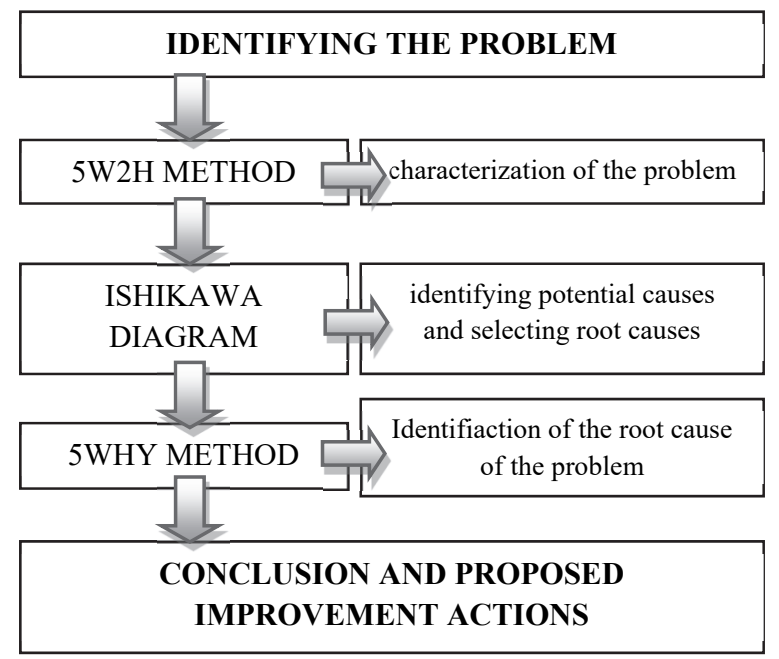

Figure 1 The sequence of quality management technique

In the first stage of analysis after the detection of nondestructions on product, the $5 \mathrm{~W} 2 \mathrm{H}$ method was used. The $5 \mathrm{~W} 2 \mathrm{H}$ method was applied twice in order to characterize the incompatibilities which were identified on the fourhole flange bearing housing and gasodynamic sealant. The method consisted in asking seven questions, thanks to which it was possible to collect the most important information on incompatibilities. Next, in order to identify the potential causes of incompatibilities the Ishikawa diagram was drawn. Because on the two products the same type of incompatibilities was identified, i.e. linear indications, only one Ishikawa diagram was made. The problem was recorded in the fish head (linear indications). Next, the basic categories of the Ishikawa diagram were selected for analysis (i.e. rule $5 \mathrm{M}+\mathrm{E}$ ) i.e. man, machine, method, material, management and environment, which were considered adequate to analysing incompatibilities [22-28]. Potential causes of linear indications on the products were assigned to those categories. The use of the cause and effect diagram made it possible to analyze incompatibilities and select from the potential causes the main ones, so it was possible to make the next analyses (5Why) in order to identify the source cause [29]. To identify the source cause of linear indications on products the 5 Why method was used. The main reasons was asked "Why?". 
After identifying the source cause, improvement actions were proposed in order to eliminate or minimize the occurrence of linear indications on the four-hole flange bearing housing and gasodynamic sealant. The questions were asked up to the moment in which the answer gives the chance to undertake a specific improvement action.

\section{ANALYSIS}

After non-destructive testing using the fluorescence method for the four-hole flange bearing housing and using the magnetic-powder method for the gasodynamic sealant, the incompatibilities were identified - which were the linear indications (Fig. 2).
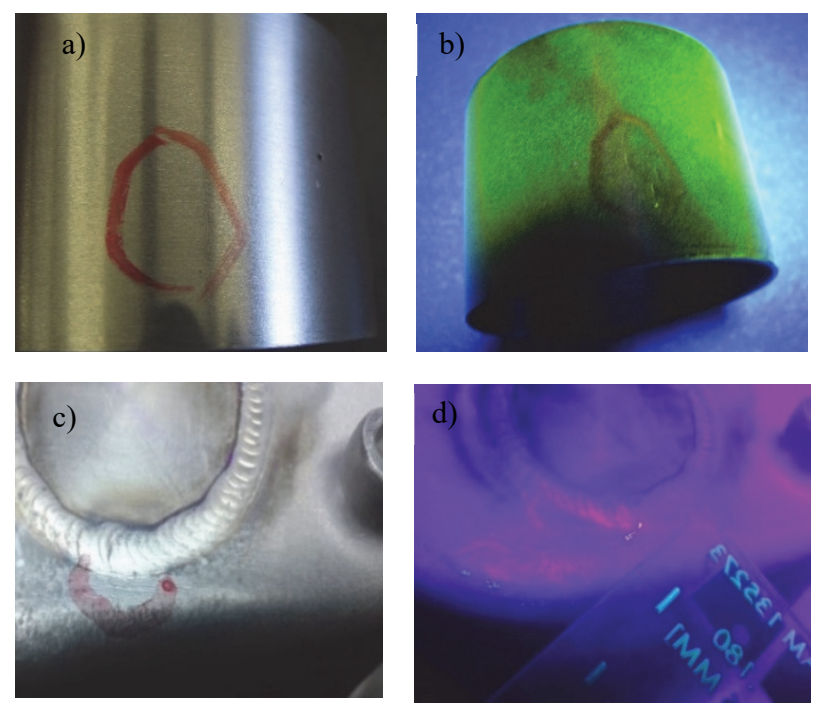

Figure 2 The linear indications: a), b) on the gasodynamic sealant; c), d) on the bearing housing
In order to characterize the problem, the $5 \mathrm{~W} 2 \mathrm{H}$ method was performed twice - for the problem of linear indications on the flange four-hole bearing housing and for the problem of linear indications on the gasodynamic sealant (Tab. 2).

Table 2 The $5 \mathrm{~W} 2 \mathrm{H}$ method for the problem of linear indications

\begin{tabular}{|c|c|c|}
\hline \multicolumn{3}{|c|}{$\begin{array}{l}\text { 5W2H METHOD } \\
\text { for the problem of linear indications }\end{array}$} \\
\hline \multirow{2}{*}{ Question } & \multicolumn{2}{|c|}{ Answer } \\
\hline & bearing housing & gasodynamic sealent \\
\hline $\begin{array}{l}\text { Who noticed a } \\
\text { problem }\end{array}$ & $\begin{array}{c}\text { an employee } \\
\text { examining the product } \\
\text { using the fluorescent } \\
\text { method }\end{array}$ & $\begin{array}{l}\text { an employee examining } \\
\text { the product using the } \\
\text { magnetic-powder method }\end{array}$ \\
\hline $\begin{array}{l}\text { What was the } \\
\text { problem? }\end{array}$ & linear indications & linear indications \\
\hline $\begin{array}{l}\text { Why was it a } \\
\text { problem? }\end{array}$ & $\begin{array}{l}\text { exceeding the } \\
\text { permissible size }\end{array}$ & $\begin{array}{l}\text { exceeding the permissible } \\
\text { size }\end{array}$ \\
\hline $\begin{array}{l}\text { Where was the } \\
\text { problem } \\
\text { noticed? }\end{array}$ & $\begin{array}{l}\text { on the surface of the } \\
\text { product }\end{array}$ & $\begin{array}{l}\text { on the surface of the } \\
\text { product }\end{array}$ \\
\hline $\begin{array}{l}\text { When was the } \\
\text { problem } \\
\text { noticed? }\end{array}$ & $\begin{array}{l}\text { during the fluorescence } \\
\text { study }\end{array}$ & $\begin{array}{l}\text { during the magnetic- } \\
\text { powder test }\end{array}$ \\
\hline $\begin{array}{l}\text { How was the } \\
\text { problem } \\
\text { noticed? }\end{array}$ & fluorescent method & magnetic-powder method \\
\hline $\begin{array}{l}\text { How big was the } \\
\text { problem? }\end{array}$ & 1 & 1 \\
\hline
\end{tabular}

Next, the Ishikawa diagram was prepared, and because on both the gasodynamic sealant and the four-hole flange bearing housing the same type of incompatibility was identified (linear indications), only one Ishikawa diagram was prepared for these problems (Fig. 3).

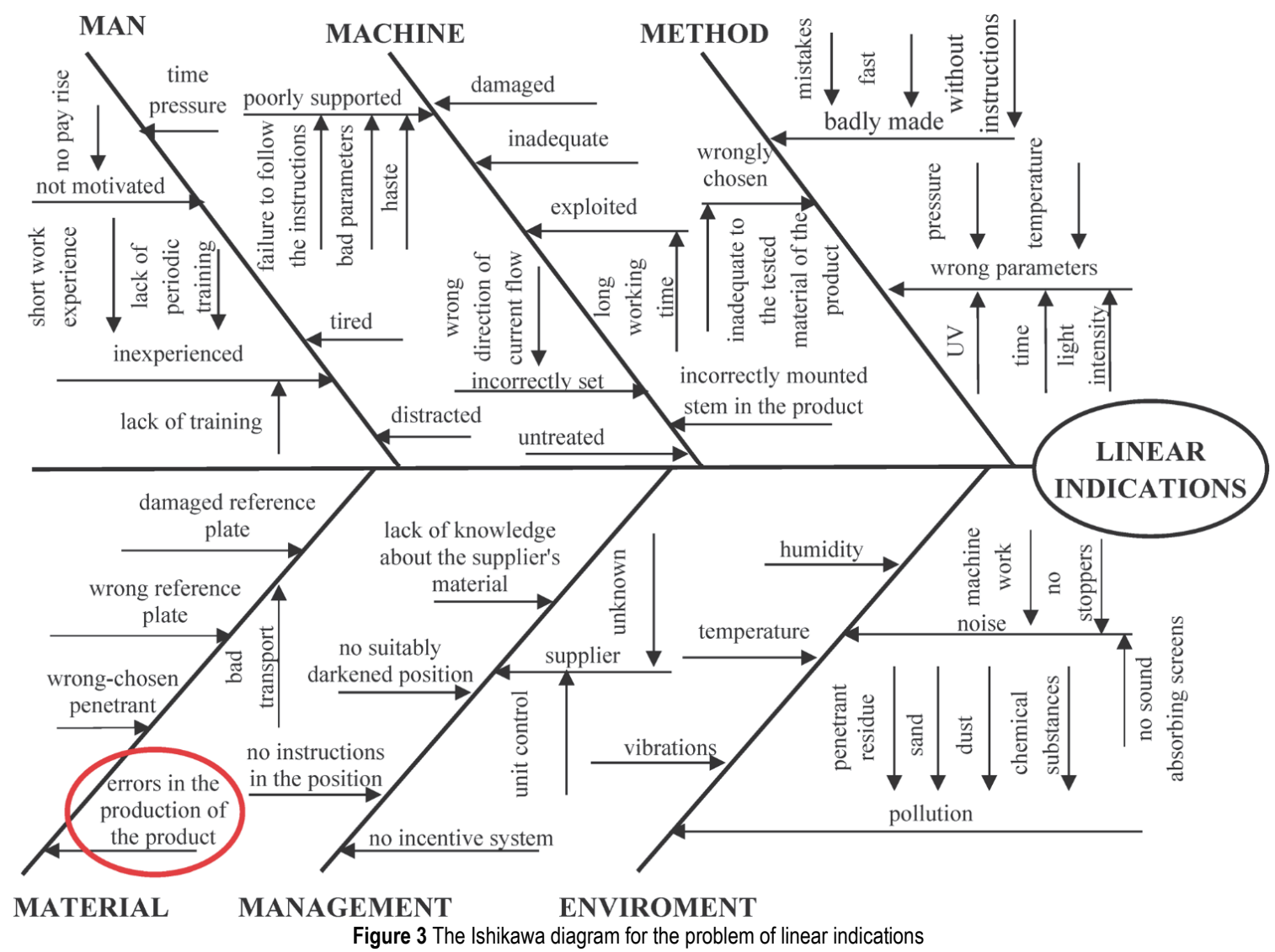


After analysing the potential causes of problem of linear indications on the gasodynamic sealent and bearing housing, it was concluded that the main cause was errors in the production of these products. This conclusion has been drawn because the incompatibility which was on the bearing housing was near the weld. And the incompatibility which was on the gasodynamic sealant was on the center outer side of the product and was very uneven. So, it was pointed out that the main cause was errors in the production.

The analysis with the use of the 5 Why method was made for the problem of linear indications on the selected products in order to identify the source cause of the problem. An example of the 5Why analysis carried out is shown in Fig. 4. After the analysis of the problem with the use the 5Why method it was concluded that the source causes of linear indications on the gasodynamic sealant and bearing housing were inconsistencies arising during the production of products from the product supplier who ordered the inspection.

After using the quality management techniques with the non-destructive test, and identifying the source of cause, under the improvement actions the production enterprise was informed about the source of the problem. But in order to eliminate this problem, it is necessary to make improvements actions in production enterprises. And after improvement actions, it is necessary to check this effect by other methods such as for example FMEA.

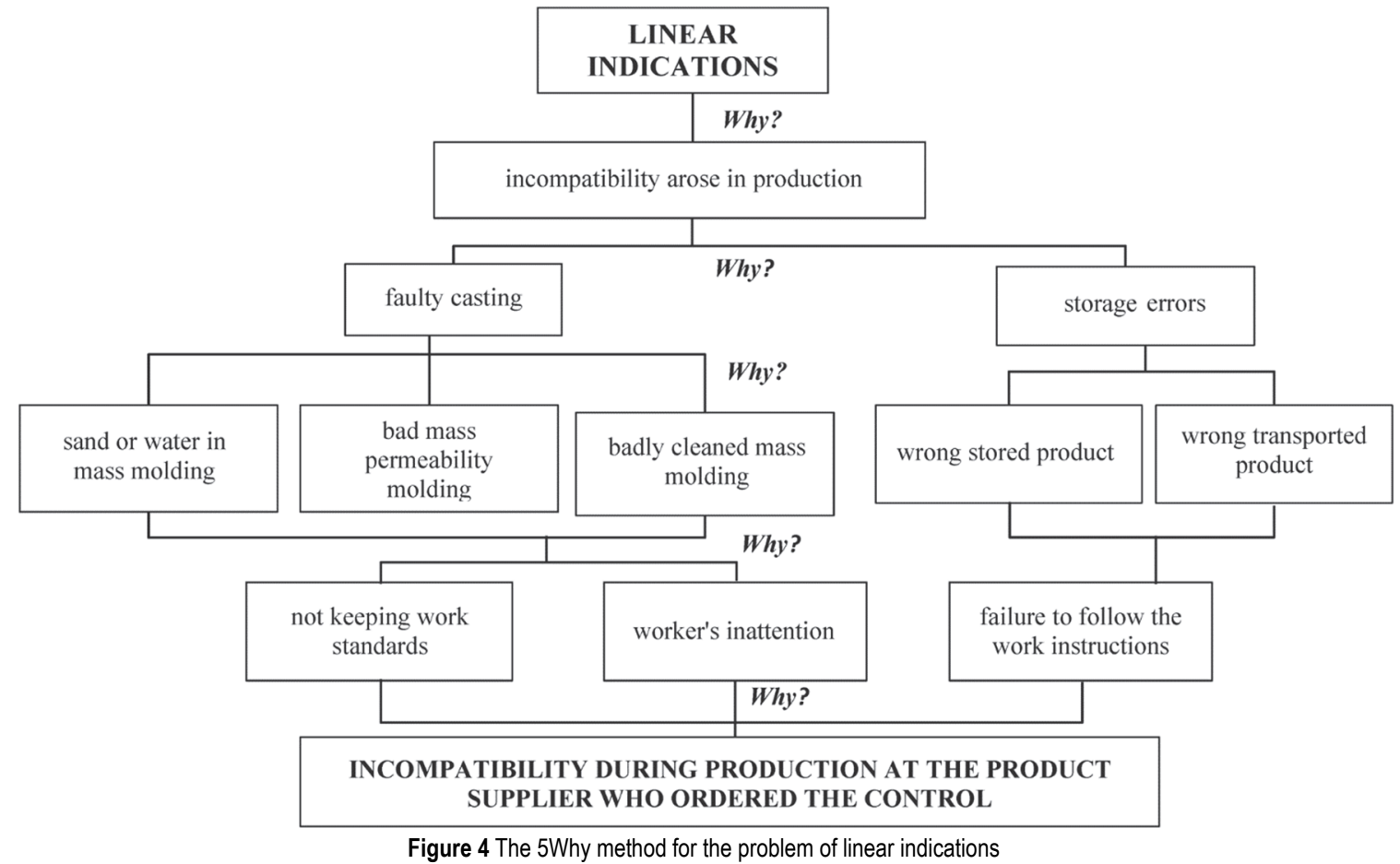

\section{CONCLUSION}

The non-destructive testing due to its specificity as well as low costs is often used in the quality testing of products. As part of continuous improvement of quality in well-managed enterprises, identification of incompatibilities should initiate actions aimed at finding their causes. In order to skilfully do this, you can use the selected quality management techniques. Such use of quality management techniques and non-destructive testing was proposed to increase the efficiency of identifying the root cause of the problem. These products were: the four-hole flange bearing housing and gasodynamic sealant. Due to the possibility of making effective, uncomplicated quality analyzes of products at relatively low costs of services (compared to other nondestructive testing methods) the fluorescent method and magnetic-powder method were used in the enterprise, so the integrated quality management techniques were implemented in the process of research using these methods. The choice of the method for the analysis of the product was conditioned by the type of material from which the products were made, as well as the order from external customers. Because the magnetic-powder method has application only to the ferromagnetic material, so the gasodynamic sealant was analyzed by this method. In turn the four-hole flange bearing housing was analyzed by the fluorescent method. After performing the tests with selected methods, they identified the incompatibilities (linear indications). Next, after identifying the incompatibilities as part of the continuous improvement of quality the quality management techniques $(5 \mathrm{~W} 2 \mathrm{H}$ method, Ishikawa diagram and 5Why method) were used in integrated manner. The $5 \mathrm{~W} 2 \mathrm{H}$ method was used to characterize the problem (linear indications). The analysis was made twice (using the 5W2H method), because two products were analyzed, so the analysis was made for the problem with linear indications on the gasodynamic sealant and the problem with linear indications on the bearing housing. Using this method, it was possible to gather the most important information on incompatibilities with seven questions. Next, the analysis of the problem was made by using the Ishikawa diagram. Because the same type of problem (linear indications) was identified on the gas-dynamic sealant and flange four-hole bearing housing, the analysis was performed using one Ishikawa diagram. 
By this diagram the potential causes and the main causes of the problem were identified (errors in the production of the product). After identifying the main cause of the problem, it was possible to use the 5 Why method, thanks to which the source cause of the linear indications was identified. The source cause was incompatibility created during the production of the product at the product supplier who ordered the inspection. On the example of two methods included in non-destructive testing, i.e. fluorescent method and magnetic-powder method, it has been concluded that it is efficient to integrate quality management techniques into qualitative analyses in order to identify the root cause of the problem. The techniques practiced sequentially present a complete and easy in practice possibility of qualitative analysis to identify the cause of the source incompatibility. It has been demonstrated that the implementation of quality management techniques in the non-destructive testing process is the way to effectively manage quality, which can also be used to solve other problems, in other enterprises as well, as part of improving production processes. After using these not complicated methods, it will be effective to use more advanced methods such as 8D, Six Sigma and DMAIC, in the appropriate sequence.

\section{REFERENCES}

[1] Antin, K.-N., Machado, M. A., Santos, T. G., \& Vilaça, P. (2019). Evaluation of Different Non-destructive Testing Methods to Detect Imperfections in Unidirectional Carbon Fiber Composite Ropes. Journal of Nondestructive Evaluation, 38(1), 23-38. https://doi.org/10.1007/s10921-019-0564-y

[2] McCann, D. M. \& Forde, M. C. (2001). Review of NDT methods in the assessment of concrete and masonry structures. NDT E Int., 34(2), 71-84. https://doi.org/10.1016/S0963-8695(00)00032-3

[3] Zielińska, M. \& Rucka, M. (2018). Non-destructive assessment of masonry pillars using ultrasonic tomography. Materials, 11(12), 1-16. https://doi.org/10.3390/ma11122543

[4] Gawdzińska, K. (2017). Methods of the detection and identification of structural defects in saturated metallic composite castings. Archives of Foundry Engineering, 17(3), 37-44. https://doi.org/10.1515/afe-2017-0087

[5] Sukhanov, A. V., Artemova, A. I., \& Litvinenko, R. S. (2017). The non-destructive test method as a simple way to evaluate the quality of metal core PCBS for high power micro-assemblies. Indonesian Journal of Electrical Engineering and Computer Science, 8(2), 281-286. https://doi.org/10.11591/ijeecs.v8.i2.pp281-286

[6] Markus, S., Fox, C., Kurz, W. et al. (2018). Characterization of steel buildings by means of non-destructive testing methods. Journal of Mathematics in Industry, 8(1), 1-17. https://doi.org/10.1186/s13362-018-0052-5

[7] Mahal, H. N., Yang, K., \& Nandi, A. K. (2019). Improved defect detection using adaptive leaky NLMS filter in guidedwave testing of pipelines. Applied Sciences (Switzerland), 9(2), 294. https://doi.org/10.3390/app9020294

[8] Dinda, S. K., Kar, J., Jana, S., Gopal Roy, G., \& Srirangam, P. (2019).Effect of beam oscillation on porosity and intermetallics of electron beam welded DP600-steel to Al 5754-alloy. Journal of Materials Processing Technology, 265(1), 191-200. https://doi.org/10.1016/j.jmatprotec.2018.10.026

[9] Liu, D., Chao, C., Jin, W., \& Chen, L. (2018). Nondestructive Measurement of Al Alloy Surface Strengthening Layer Depth Using Swept Frequency Eddy
Current Testing. IOP Conference Series: Materials Science and Engineering, 392(2), 022027. https://doi.org/10.1088/1757-899X/392/2/022027

[10] Cung, L. T., Dao, T. D., Nguyen, P. C., \& Bui, T. D. (2018). A model-based approach for estimation of the crack depth on a massive metal structure. MATEC Web of Conferences, 51(5-6), 182-191. https://doi.org/10.1177/0020294018778314

[11] Kahrobaee, S. \& Zohourvahid Karimi, E. (2019). Characterisation of work-hardening in Hadfield steel using non-destructive eddy current method. Nondestructive Testing and Evaluation, 34(2), 178-192. https://doi.org/10.1080/10589759.2019.1581190

[12] Matsumoto, T., Uchimoto, T., Takagi, T. et al. (2019. Investigation of electromagnetic nondestructive evaluation of residual strain in low carbon steels using the eddy current magnetic signature (EC-MS) method. Journal of Magnetism and Magnetic Materials, 479, 212-221. https://doi.org/10.1016/j.jmmm.2019.01.103

[13] Hughes, R. R. \& Dixon, S. (2019). Performance analysis of single-frequency near electrical resonance signal enhancement (SF-NERSE) defect detection. NDT and E International, 102(1), 96-103. https://doi.org/10.1016/j.ndteint.2018.11.008

[14] Lu, X., Zheng, G. G., \& Zhou, P. (2019). High performance refractive index sensor with stacked two-layer resonant waveguide gratings. Results in Physics, 12, 759-765. https://doi.org/10.1016/j.rinp.2018.12.048

[15] Hristoforou, E. (2018). Advanced Non-Destructive Testing in Steels. Metals, 8,492. https://doi.org/10.3390/met8070492

[16] Kumar, T. P. \& Reddy, P. P. (2018). Non-Destructive Analysis of FSW Process and Comparison with Simulation and Microstructural Analysis. Procedia Manufacturing, 20(1), 187-194. https://doi.org/10.1016/j.promfg.2018.02.027

[17] Schuller, M. P. (2003). Nondestructive testing and damage assessment of masonry structures. Progress in Structural Engineering and Materials banner, 5(4), 239-251. https://doi.org/10.1002/pse.160

[18] Das, P. C., Hardy, M. S. A., McCann, D. N., \& Forde, M. C. (2000). Specifications for competitive tendering of NDT inspection of bridges. Bridge management four, 568-576.

[19] Vasanelli, E., Sileo, M., Leucci, G., Calia, A., Aiello, M. A., \& Micelli, F. (2015). Mechanical characterization of buildingstones through DT and NDT tests: Research of correlations for the in situ analysis of ancient masonry. Key Engineering Materials, 628, 85-89. https://doi.org/10.4028/www.scientific.net/KEM.628.85

[20] Pouranvari, M., Ekrami, A., \& Kokabi, A. H. (2014). Diffusion brazing of cast INCONEL 718 superalloy utilising standard heat treatment cycle. Materials Science and Technology, 30(1), 109-115. https://doi.org/10.1179/1743284713Y.0000000320

[21] Baghjari, S. H., Ghaini, F. M., Shahverdi, H. R. et al. (2016). Characteristics of electrospark deposition of a nickel-based alloy on 410 stainless steel for purpose of facilitating dissimilar metal welding by laser. International Journal of Advanced Manufacturing Technology, 87, 2821-2828. https://doi.org/10.1007/s00170-016-8668-3

[22] Bilsel, R. U. \& Lin, D. K. J. (2012). Ishikawa Cause and Effect Diagrams Using Capture Recapture Techniques. Quality Technology and Quantitative Management, 9(2), 137-152. https://doi.org/10.1080/16843703.2012.11673282

[23] Pacana, A. et al. (2015). The study of stickiness of packaging film by Shainin method. Przemyst Chemiczny, 94(8), 13341336.

[24] Chokkalingam, B., Raja, V., Anburaj, J. et al. (2017). Investigation of Shrinkage Defect in Castings by Quantitative Ishikawa Diagram. Archives of Foundry Engineering, 17, 174-178. https://doi.org/10.1515/afe-2017-0032 
[25] Pacana, A., Bednárová, L., Liberko, I. et al. (2014). Effect of selected production factors of the stretch film on its extensibility. Przem. Chem., 93(7), 1139-1340.

[26] Salvador, C. G. (2004). Goldfarb N. Ishikawa cause and effect diagrams: A useful tool in designing economic analyses. Value in Health, 7, 301-302.

https://doi.org/10.1016/S1098-3015(10)62317-0

[27] Pacana, A., Czerwińska, K., \& Siwiec, D. (2018). Tools and methods of quality management. Oficyna Wydawnicza Stowarzyszenia Menedżerów Jakości $i$ Produkcji, Częstochowa.

[28] Malindzak, D., Pacana, A., \& Pacaiova, H. (2017). An effective model for the quality of logistics and improvement of environmental protection in a cement plant, Przem. Chem., 96(9), 1958-1962.

[29] Benjamin, S., Marathamuthu, M., \& Murugaiah, U. (2015). The use of 5-WHYs technique to eliminate OEE's speed loss in a manufacturing firm. Journal of Quality in Maintenance Engineering, 21(4), 419.

https://doi.org/10.1108/JQME-09-2013-0062

\section{Contact information:}

Andrzej PACANA, DSc, Associate Professor

(Corresponding author)

Faculty of Mechanical Engineering and Aeronautics,

Rzeszow University of Technology,

Al. Powstańców Warszawy 12, 35-959 Rzeszów, Poland

E-mail: app@prz.edu.pl

\section{Dominika SIWIEC, MSc}

Faculty of Mechanical Engineering and Aeronautics,

Rzeszow University of Technology,

Al. Powstańców Warszawy 12, 35-959 Rzeszów, Poland

E-mail: d.siwiec@prz.edu.pl 